\title{
Effects of Sulfur and Calcium Compounds on Dioxin Reduction in a Fluidized Bed Combustor
}

\author{
Hung-Ming Shen ${ }^{1}$, Ya-Fen Wang ${ }^{2}$, Chien-Song Chyang ${ }^{1 *}$, Wei-Chih Wang ${ }^{1}$, Geng-Min Lin ${ }^{1}$ \\ ${ }^{I}$ Department of Chemical Engineering Research Center for Circular Economy, Chung Yuan Christian University, \\ Taoyuan 32023, Taiwan \\ ${ }^{2}$ Department of Environmental Engineering, Chung Yuan Christian University, Taoyuan 32023, Taiwan
}

\begin{abstract}
The focus of this study is the effects of sulfur and calcium compounds on reducing dioxins in fly ash collected from the baghouse of a pilot-scale fluidized bed combustor. Pelletized sawdust with various amounts of polyvinyl chloride (PVC), pyrite, and calcium hydroxide was used as the feeding material. The experimental results indicated an extremely low concentration of dioxin in the fly ash from the cyclone $\left(0.025\right.$ to $\left.0.284 \mathrm{ng} \mathrm{g}^{-1}\right)$, and the concentrations of polychlorinated dibenzo- $p$-dioxins and dibenzofurans (PCDD/Fs) in the fly ash collected from the baghouse increased by $27.4 \%$ as the chlorine content increased from 0.568 to $1.136 \mathrm{wt} \%$. The inhibition of PCDD/Fs by sulfur is not clear and can be attributed to the low content of copper (average $387 \mathrm{ppm}$ ), which serves as the catalyst for the Deacon reaction. Octa-chlorinated dibenzofuran (OCDF) was the major congener of the PCDD/Fs. The highest toxicity-equivalent (I-TEQ) of 2,3,7,8substituted congeners was 2,3,4,7,8-PeCDF, which accounted for $37 \%$ of the total congeners (average value). The correlation between the I-TEQ values and 2,3,4,7,8-PeCDF concentration of fly ash is also discussed.
\end{abstract}

Keywords: Dioxin; Fly ash; Sulfur compound; Calcium compound; Fluidized bed combustor.

\section{INTRODUCTION}

Polychlorinated dibenzo- $p$-dioxins and dibenzofuran (PCDD/Fs) emissions from incineration processes were first reported by Olie et al. (1977). The main cause of dioxin generation is the chlorine content of the feeding material used in the incineration process (Hatanaka et al., 2000; Wang et al., 2003; Stanmore, 2004). Mattila et al. (1992) found that a large amount of PCDD/Fs was generated when the chlorine content of the feeding material was increased from $0.4 \%$ to $1.2 \%$. Some studies (Lenoir et al., 1991; Frankenhaeuser et al., 1993; Halonen et al., 1993; Ruuskanen et al., 1994) found that when the chlorine content in the fuel is below $1 \%$, the levels of PCDD/Fs in the flue are approximately the same. However, the formation of dioxin increases significantly when the chlorine content of the feeding material exceeds 1\% (Wikström et al., 1996).

Numerous studies have been conducted to determine effective methods of inhibiting or reducing dioxin formation during the combustion process. Griffin (1986) presented a

\footnotetext{
* Corresponding author.

Tel.: +886 3 2654119; Fax: +88634636242

E-mail address: cschyang@cycu.edu.tw;

cschyang@gmail.com
}

mechanism involving sulfur as an inhibitor of dioxin formation, and similar methods have also been proposed by other researchers (Stieglitz et al., 1990; Stieglitz et al., 1991; Gullett et al., 1992a, b; Lindbauer et al., 1992, 1993; Ogawa et al., 1996; Raghunathan and Gullett, 1996; Preto et al., 2005). Gullett et al. (1992b) suggested that the reaction of $\mathrm{Cu}$ (II) with $\mathrm{SO}_{2}$ to form $\mathrm{CuSO}_{4}$ renders the catalyst less active, thus decreasing PCDD formation. This finding was supported by the results obtained by Ryan et al. (2006) and Ke et al. (2010). Lin et al. (2015) found that the amount of PCDD/Fs can be reduced by $94 \%$ with the addition of pyrite $\left(\mathrm{FeS}_{2}\right)$.

Ogawa et al. (1996) found that the inhibitory effect was increased when the $\mathrm{S} / \mathrm{Cl}$ ratio ranged from 0.1 to 0.65 , and Anthony et al. (2001) stated that the sulfur contained in fuel can be used to reduce dioxin formation, which is considered to depend on the $\mathrm{S} / \mathrm{Cl}$ ratio. Their results showed that the addition of sulfur at a higher ratio $(\mathrm{S} / \mathrm{Cl}>1)$ appeared to reduce the emission of PCDD/Fs; however, no benefit was derived from addition of higher amounts of sulfur $(\mathrm{S} / \mathrm{Cl}>2)$. Chang et al. (2006) found that PCDD/Fs formation can be decreased to $54.1 \%$ by adding sulfur at a $\mathrm{S} / \mathrm{Cl}$ ratio of approximately 2 in a laboratory-scale system. As mentioned above, the efficiency of reducing PCDD/Fs formation by adding sulfur is strongly influenced by the $\mathrm{S} / \mathrm{Cl}$ molar ratio, and no benefit was derived from further increasing the sulfur levels $(\mathrm{S} / \mathrm{Cl}>2)$. However, the absolute 
quantities of sulfur and chlorine have not been indicated. The levels of PCDD/Fs produced by the combustion of fuel flue are similar when the chlorine content of the fuel is lower than $1 \%$, and dioxin formation significantly increases when the chlorine content exceeds $1 \%$. The effect of the $\mathrm{S} / \mathrm{Cl}$ ratio on dioxin formation may also depend on the absolute quantity of sulfur or chlorine.

Calcium oxide can effectively control the emissions of dioxin and acid gas from municipal waste incineration systems (Liu et al., 2000). Bie et al. (2005) observed the highest conversion rate for the chlorination of calcium oxide in fluidized bed combustion at $600^{\circ} \mathrm{C}$. Lawrence and $\mathrm{Bu}$ (2000) stated that the calcium oxide entrained into the freeboard at $650^{\circ} \mathrm{C}$ has a better hydrogen chloride removal efficiency. Kobyashi et al. (2005) stated that Ca-based substances can be used to remove hydrogen chloride in a fluidized bed, even at temperatures exceeding $1000 \mathrm{~K}$. The results of recent research indicate that the simultaneous desulfurization and dechlorination are possible at high temperatures in a furnace (Lin and Chyang, 2016).

Hung et al. (2018) indicated that total PCDD/Fs concentrations ranging from $45.5 \%$ to $73.8 \%$ were partitioned in the solid phase. Activated carbon (AC) injections have been used to reduce the dioxin in flue gas for a long time. Buekens and Huang (1998) demonstrated that a dioxin removal efficiency of $95 \%$ can be achieved by using an AC moving bed, while that from using a fixed bed was approximately $80 \%$. Chiang et al. (2000) indicated that a fluidized bed activated carbon adsorber has a high removal efficiency of polycyclic aromatic hydrocarbons (PAHs). Wang et al. (2009) found that the concentrations of PCDD congeners at the stack and PCDFs decreased from 117.00 to $0.32 \mathrm{ng} \mathrm{Nm}^{-3}$ and 94.84 to $0.19 \mathrm{ng} \mathrm{Nm}^{-3}$ when the injection of AC increased from 10 to $17 \mathrm{~kg} \mathrm{~h}^{-1}$ at a mean flue gas rate of $1600 \mathrm{Nm}^{3} \mathrm{~min}^{-1}$, respectively. A multilayer AC-adsorption system (MAS) was developed to improve the control of PCDD/Fs emissions (Chi et al., 2008; Lin et al., 2008; Hung et al., 2011; Cui et al., 2017).

Recently, several studies focused on the effects of sulfur or calcium compounds on dioxin emissions in flue gas (Chyang et al., 2010; Li et al., 2015; Lin et al., 2015; Ma et al., 2018). Few studies have discussed the effects of sulfur and calcium compounds on the dioxin content of fly ash (Hajizadeh et al., 2012), and the effects of calcium oxide, sulfur, and dioxin emission control have been discussed separately (Chyang et al., 2010). However, comprehensive studies are minimal. Calcium can simultaneously desulfurize and dechlorinate substances at high temperatures (Lin and Chyang, 2016), but experimental data regarding the effects of dioxin formation are still required. The purpose of this study is to investigate the relationship between sulfide, calcium, and the dioxin in fly ash. The inhibitory effects of adding calcium/sulfur on dioxin in fly ash are also investigated. To remove the influence of activated carbon on the dioxin in fly ash, activated carbon injection is not used in this study.

\section{METHODS}

\section{Material}

Pelletized wood sawdust with various additives (PVC, pyrite, and calcium hydroxide) and varied amounts of chlorine, sulfur, and calcium were used as the feeding material. In the granulation process, a small amount of composite-modified starch was added to increase the cohesive force and shape the sawdust into pellets. Each pellet was $6 \mathrm{~mm}$ in diameter with a mean length of $15 \mathrm{~mm}$. The results of the proximate and ultimate analyses of the pelletized wood sawdust are provided in Table 1, while the composition of each feeding material is shown in Table 2. Only PVC was added to group B. PVC and pyrite were added to group $\mathrm{C}$, with a $\mathrm{S} / \mathrm{Cl}$ ratio below 1 , and $\mathrm{PVC}$ was added to group $\mathrm{S}$, with a $\mathrm{S} / \mathrm{Cl}$ ratio exceeding 1 . Under the criterion of $\mathrm{Ca} /(\mathrm{S}+0.5 \mathrm{Cl})=1.98$, calcium hydroxide was added to feeding materials $\mathrm{C} 2, \mathrm{C} 4, \mathrm{~S} 2$, and S4. Silica sand $\left(99.5 \% \mathrm{SiO}_{2}\right)$ with a mean diameter of $0.506 \mathrm{~mm}$ and apparent density of $2600 \mathrm{~kg} \mathrm{~m}^{-3}$ was used as the inert bed material in this study.

\section{Experimental Apparatus}

All of the experiments were conducted in a bubbling fluidized-bed combustion (BFBC) system, as shown in Fig. 1, and the configuration of the bubbling fluidized-bed combustor is shown in Fig. 2. The combustor was divided into four parts, i.e., the wind box, distributor, combustion chamber, and freeboard. The combustion chamber had a cross-section of $0.8 \times 0.4 \mathrm{~m}$ and was constructed from $6-\mathrm{mm}$ carbon steel lined with a $150-\mathrm{mm}$ refractory to reduce heat

Table 1. Proximate and ultimate analyses of the feeding materials.

\begin{tabular}{|c|c|c|c|c|c|c|c|c|c|c|}
\hline \multicolumn{5}{|c|}{ Proximately analysis (wt.\% as-received) } & \multicolumn{6}{|c|}{ Ultimate analysis (wt $\%$ Dry and ash free) } \\
\hline feeding material & Moisture & Volatile & Fixed carbon & Ash & $\mathrm{C}$ & $\mathrm{H}$ & $\mathrm{O}$ & $\mathrm{N}$ & $\mathrm{S}$ & $\mathrm{Cl}$ \\
\hline B1 & 9.86 & 75.03 & 14.09 & 1.03 & 49.87 & 6.65 & 42.58 & 0.26 & 0.06 & 0.57 \\
\hline B2 & 10.24 & 74.54 & 13.87 & 1.36 & 49.71 & 6.71 & 42.16 & 0.23 & 0.04 & 1.15 \\
\hline $\mathrm{C} 1$ & 10.65 & 73.58 & 14.26 & 1.52 & 50.00 & 6.62 & 42.11 & 0.29 & 0.40 & 0.57 \\
\hline $\mathrm{C} 2$ & 9.38 & 74.31 & 14.39 & 1.93 & 49.22 & 6.70 & 42.84 & 0.24 & 0.41 & 0.58 \\
\hline $\mathrm{C} 3$ & 10.88 & 74.03 & 13.51 & 1.58 & 49.08 & 6.29 & 42.39 & 0.29 & 0.80 & 1.14 \\
\hline C4 & 10.52 & 73.46 & 13.11 & 2.90 & 47.07 & 6.42 & 44.29 & 0.23 & 0.82 & 1.17 \\
\hline S1 & 10.72 & 72.73 & 13.90 & 2.65 & 48.94 & 6.54 & 42.89 & 0.25 & 0.80 & 0.57 \\
\hline $\mathrm{S} 2$ & 11.85 & 72.66 & 13.05 & 2.44 & 47.58 & 6.47 & 44.29 & 0.25 & 0.82 & 0.58 \\
\hline S3 & 10.55 & 74.23 & 13.41 & 1.82 & 47.53 & 6.35 & 43.05 & 0.31 & 1.61 & 1.15 \\
\hline S4 & 9.88 & 73.25 & 13.55 & 3.32 & 46.55 & 6.23 & 44.04 & 0.27 & 1.70 & 1.21 \\
\hline
\end{tabular}


Table 2. Composition of the feeding materials.

\begin{tabular}{|c|c|c|c|c|c|c|c|c|c|c|}
\hline \multirow{3}{*}{ Additives } & \multicolumn{2}{|c|}{ Chlorine } & \multicolumn{4}{|c|}{ Sulfur $<$ Chlorine } & \multicolumn{4}{|c|}{ Sulfur $>$ Chlorine } \\
\hline & \multirow{2}{*}{$\begin{array}{l}\text { Low } \\
\text { (B1) }\end{array}$} & \multirow{2}{*}{$\begin{array}{l}\text { High } \\
\text { (B2) }\end{array}$} & \multicolumn{2}{|c|}{ High } & \multicolumn{2}{|c|}{ High } & \multicolumn{2}{|c|}{ Low } & \multicolumn{2}{|c|}{ High } \\
\hline & & & (C1) & (C2) & (C3) & (C4) & (S1) & (S2) & (S3) & (S4) \\
\hline $\mathrm{FeS}_{2}(\mathrm{wt} \%)$ & - & - & 0.750 & 0.750 & 1.500 & 1.500 & 1.500 & 1.500 & 3.000 & 3.000 \\
\hline $\mathrm{S}(\mathrm{wt} \%)$ & - & - & 0.400 & 0.400 & 0.800 & 0.800 & 0.800 & 0.800 & 1.599 & 1.599 \\
\hline PVC (wt\%) & 1.000 & 2.000 & 1.000 & 1.000 & 2.000 & 2.000 & 1.000 & 1.000 & 2.000 & 2.000 \\
\hline $\mathrm{Cl}(\mathrm{wt} \%)$ & 0.568 & 1.136 & 0.568 & 0.568 & 1.136 & 1.136 & 0.568 & 0.568 & 1.136 & 1.136 \\
\hline $\mathrm{Ca}(\mathrm{OH})_{2}(\mathrm{wt} \%)$ & - & - & - & 3.000 & - & 6.000 & - & 4.830 & - & 9.660 \\
\hline $\mathrm{Ca}(\mathrm{wt} \%)$ & - & - & - & 1.623 & - & 3.246 & - & 2.613 & - & 5.226 \\
\hline $\mathrm{S} / \mathrm{Cl}(-)$ & - & - & 0.781 & 0.781 & 0.781 & 0.781 & 1.562 & 1.562 & 1.562 & 1.562 \\
\hline $\mathrm{Ca} /(\mathrm{S}+0.5 \mathrm{Cl})$ & - & - & - & 1.980 & - & 1.980 & - & 1.981 & - & 1.981 \\
\hline HHV(WB) & 4000.5 & 3629.3 & 3916.4 & 3939.3 & 4079.3 & 3929.4 & 4100.4 & 3858.3 & 4014.5 & 3830.9 \\
\hline LHV(WB) & 4048.2 & 3676.4 & 3550.9 & 3571.2 & 3728.2 & 3578.4 & 3737.1 & 3508.9 & 3660.5 & 3495.8 \\
\hline
\end{tabular}

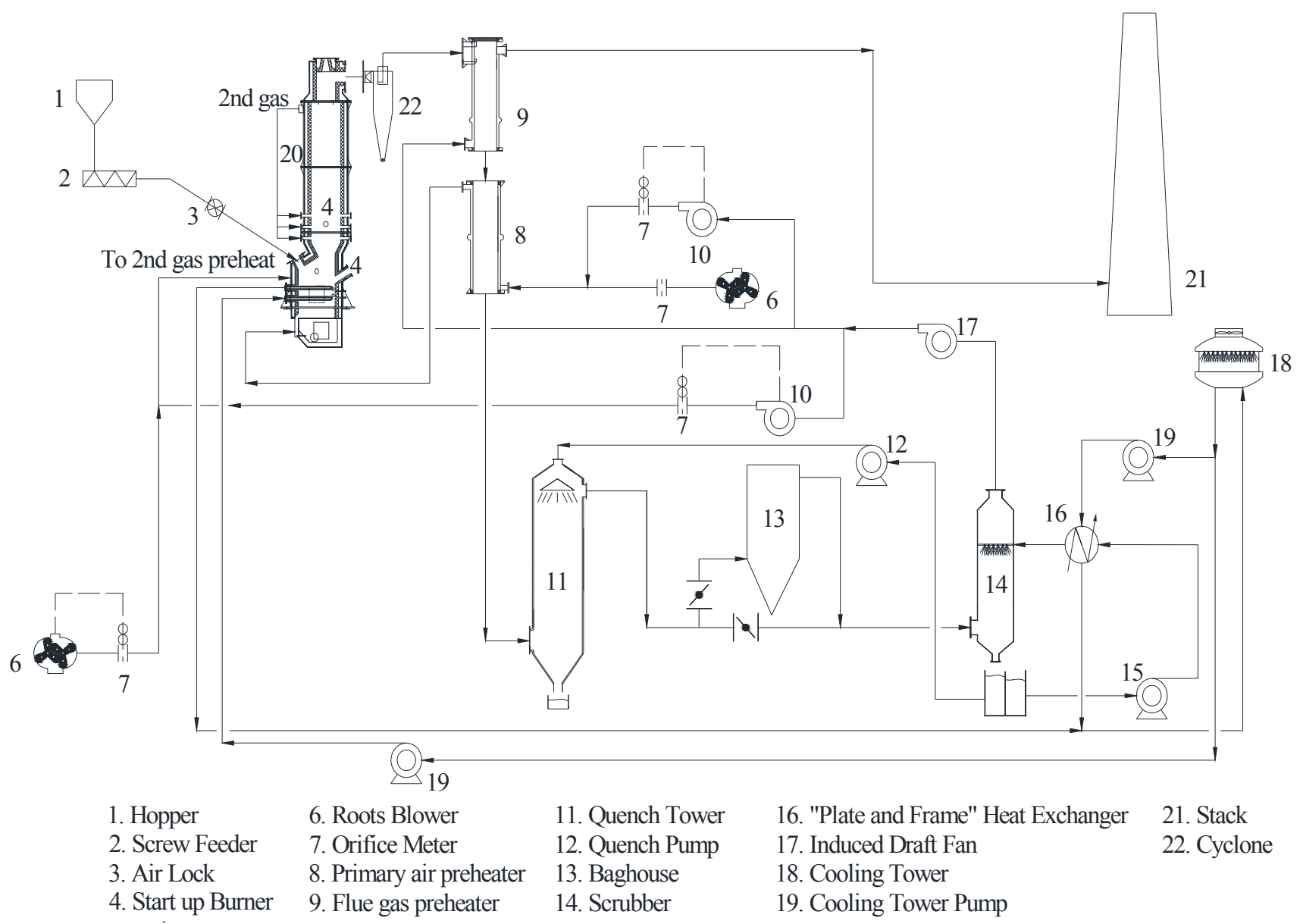

Fig. 1. Flow chart of the fluidized-bed combustion system.

loss. The freeboard with a diameter and height of 0.64 and $2.55 \mathrm{~m}$, respectively, was located above the combustion chamber. A total of 27 tuyeres with 5 and 3-mm orifices and an open-area ratio of $0.52 \%$ were mounted on a $6-\mathrm{mm}$ stainless-steel plate and used as the gas distributor. The total height of the combustor, from the distributor to the outlet, was $4.75 \mathrm{~m}$.

The over-bed feeding system was employed here. The feeding material stored in a hopper fell directly through the screw feeder and airlock and then through a water-cooled chute into the fluidized bed chamber $0.45 \mathrm{~m}$ above the distributor. The fluidizing and primary combustion air were supplied by an $11.2 \mathrm{~kW}$ Roots blower, and the secondary air was supplied by a $5.6 \mathrm{~kW}$ Roots blower. Four equally spaced secondary gas injection nozzles with diameters of $30 \mathrm{~mm}$ were installed tangentially $2.05 \mathrm{~m}$ above the distributor to generate the swirling flow in the freeboard.

The APCD is mainly used to remove particulate matter and pollutants. The flue gas from the combustor at first was introduced into heat convection sections and then input 


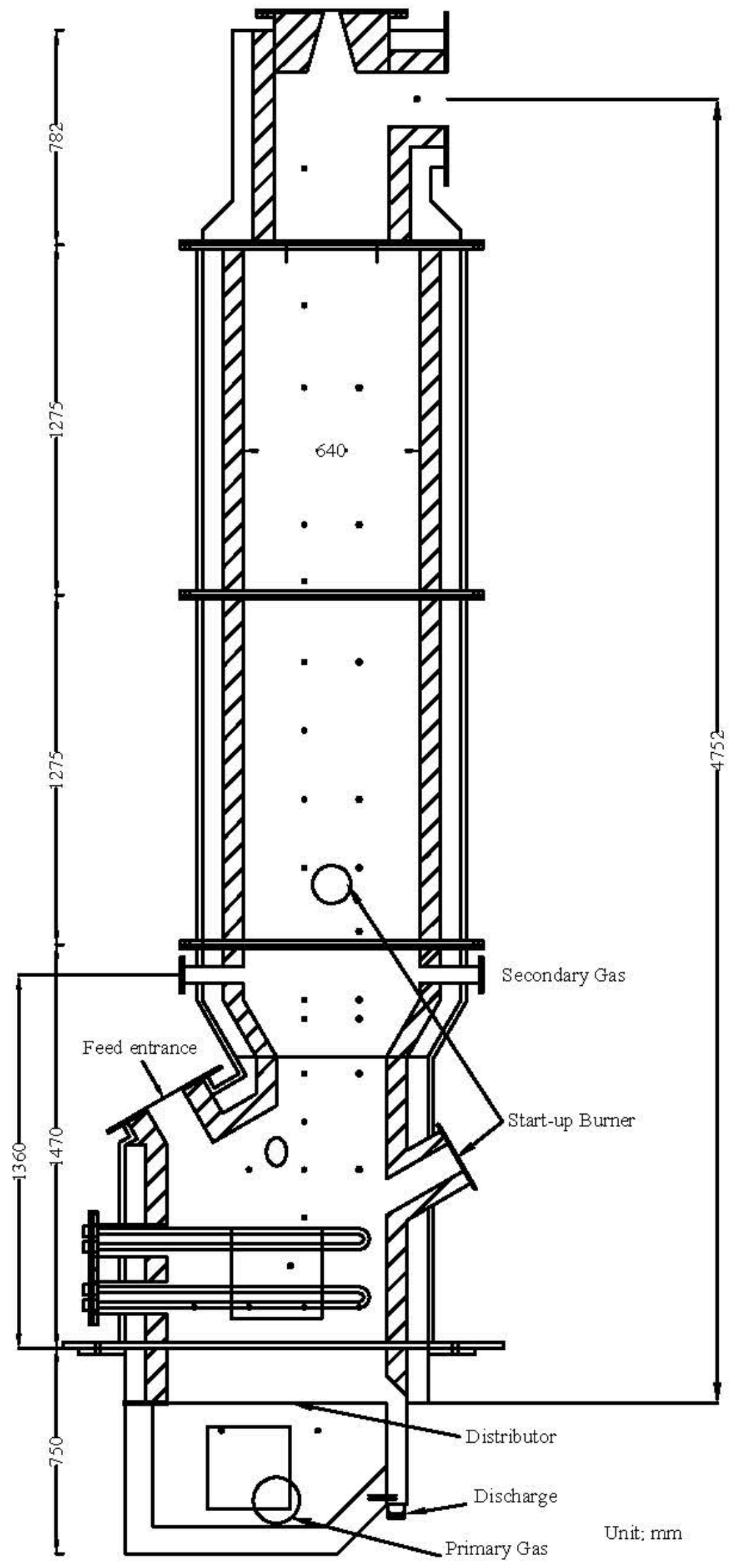

Fig. 2. Configuration of the bubbling fluidized-bed combustor. 
into a flue gas treatment system including quench tower, baghouse and scrubber. The high-temperature flue gas flows firstly through the quench tower which enables the flue gas to lower the temperature to $150^{\circ} \mathrm{C}$ for an instant. Then most of particulate matters in the low-temperature flue gas were removed after the flue gas flows through the baghouse. Subsequently the flue gas was fed into the scrubber where water was atomized into drops and sprayed with a water flow rate of $50 \mathrm{~L} \mathrm{~min}^{-1}$. Acid gases, such as $\mathrm{SO}_{2}$ and $\mathrm{HCl}$, were washed out from the flue gas. Then the flue gas was heated up to $120^{\circ} \mathrm{C}$ after flowing through a reheater and finally emitted into the atmosphere.

\section{Data Acquisition}

The PCDD/Fs content of the fly ash collected from the bottom of cyclone and the bottom of baghouse were sent to the ITRI (Industrial Technology Research Institute of Taiwan) for analysis, which was conducted using a high-resolution gas chromatography/high-resolution mass spectrometry/data system (HRGC/HRMS) (EPA Method 8290A). The HRGC and HRMS equipment were an Agilent 6890N and Thermo Finnigan MAT 95XL, respectively. The components of the flue gas, including $\mathrm{CO}, \mathrm{O}_{2}$, and $\mathrm{NO}_{\mathrm{x}}$, were analyzed using HORIBA-PG250 gas analyzers. Specifically, $\mathrm{NO}_{\mathrm{x}}$ was analyzed following the chemiluminescence detection method, with full-scale repeatability and linearity of $\pm 0.5 \%$ and $\pm 2.0 \%$, respectively. To reduce the influence of the memory effect, the sand was replaced in each experiment, and the amount of air used to blow away the fly ash in the system was increased.

\section{Experimental Conditions}

To characterize the combustion of the feeding material in the combustor, a combustion fraction model based on oxygen consumption was developed. The combustion fraction can be calculated using the following equation:

$$
Y_{i}=\frac{Q_{i n, O_{2}}-Q_{o u t, O_{2}}}{Q_{t}} \times 100 \%,
$$

where $\mathrm{Q}_{\text {in, } \mathrm{O} 2}$ and $\mathrm{Q}_{\text {out }, \mathrm{O} 2}$ are the oxygen flow rate of the inlet and outlet in each zone $\left(\mathrm{Nm}^{3} \mathrm{~min}^{-1}\right)$, respectively, and $\mathrm{Q}_{\text {TO }}$ is the total amount of oxygen consumed by the combustor $\left(\mathrm{Nm}^{3} \mathrm{~min}^{-1}\right)$.
The experimental conditions for all tests are shown in Table 3. The bed temperature was fixed at $750^{\circ} \mathrm{C}$, and the feeding rate was $35 \mathrm{~kg} \mathrm{~h}^{-1}$. The freeboard wall temperatures were fixed at 800 and $900^{\circ} \mathrm{C}$ using an on-off controlled diesel burner. To minimize the cross effects of the operating parameters, all experiments were conducted at fixed primary and secondary gas flow rates of 3 and $1 \mathrm{Nm}^{3} \mathrm{~min}^{-1}$, respectively.

\section{RESULTS AND DISCUSSION}

The experimental data for the PCDD/Fs concentration of fly ash obtained from the combustion of various feeding materials in this study are shown in Table 4. The concentration of PCDD/Fs in the fly ash collected from the baghouse ranged from 21.937 to $48.722 \mathrm{ng} \mathrm{g}^{-1}$, while that of the fly ash collected from the cyclone ranged from 0.025 to $0.284 \mathrm{ng} \mathrm{g}^{-1}$. The I-TEQ values of fly ash collected from the baghouse and cyclone ranged from 2.13 to 3.42 and 0.0012 to $0.0193 \mathrm{ng}^{\mathrm{I}-\mathrm{TEQ} \mathrm{g}^{-1}}$, respectively.

The experimental data shown in Table 4 indicate that the dioxin content of the fly ash from the cyclone was extremely low, which is similar to the results obtained by Lundin and Marklund (2007). The results of Chang and Huang (1999) also indicated that the dioxin concentration of fly ash from a baghouse is higher than that from a cyclone, and they found the PCDD/PCDF ratio of ash collected from the cyclone to be higher than that of the fly ash collected from the boiler and baghouse. This can be attributed to the dioxin formation mechanism. The condensation of a heterogeneous precursor yields more PCDDs than PCDFs (Huang and Buekens, 1995), whereas de novo synthesis yields more PCDFs than PCDDs. It is believed that the de novo synthesis of PCDD/Fs occurs in the presence of oxygen at temperatures of approximately $250-400^{\circ} \mathrm{C}$ (Vogg et al., 1987; Milligan and Altwicker, 1993; Cunliffe and Williams, 2009). Hightemperature flue gas and particles are separated by a cyclone, resulting in fly ash with a very low concentration of dioxins, and de novo synthesis is reduced due to the environment without flue gas. Song et al. (2008) found that under an anoxic or inert atmosphere at $300-600^{\circ} \mathrm{C}$, the dioxin content decreases through de-chlorination and destruction. In this study, the ash collected at the bottom of the cyclone was located in a gas flow stagnation zone that received no downward flue gas flow. Owing to the extremely

Table 3. Experimental conditions.

\begin{tabular}{ll}
\hline Operating parameter & Conditions \\
\hline Feeding material & Pelletized sawdust \\
Feeding rate $\left(\mathrm{kg} \mathrm{hr}^{-1}\right)$ & 35 \\
Excess oxygen ratio $(\%)$ & 60 \\
Bed temperature $\left({ }^{\circ} \mathrm{C}\right)$ & 750 \\
Freeboard temperature $\left({ }^{\circ} \mathrm{C}\right)$ & 800,900 \\
Primary air flow rate $\left(\mathrm{Nm}^{3} \mathrm{~min}^{-1}\right)$ & 3 \\
Secondary air flow rate $\left(\mathrm{Nm}^{3} \mathrm{~min}^{-1}\right)$ & 1 \\
Bed material & Silica sand \\
Apparent density $(\mathrm{kg} \mathrm{m})$ & 2600 \\
Average particle size of the bed material $(\mu \mathrm{m})$ & 506 \\
\hline
\end{tabular}




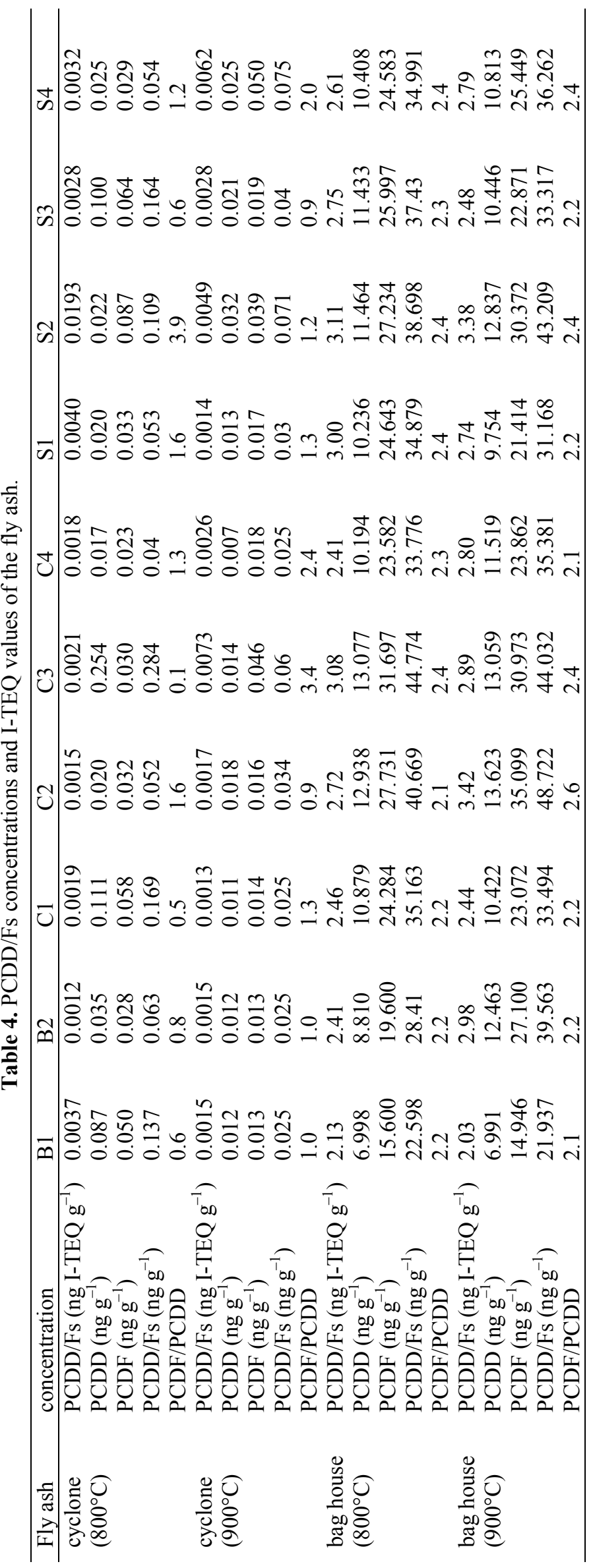


low dioxin and PCDD content of the ash, we can state that no de novo synthesis occurred in this area, and the combustion in the combustor was highly efficient. Chang and Huang (1999) found the dioxin concentration of cyclone ash to be lower than that of baghouse ash, and the PCDD > PCDF indicated that most of the dioxin concentration originated from a precursor reaction. In this study, the results obtained at $800^{\circ} \mathrm{C}$ were similar to those obtained by Chang and Huang (1999). When the freeboard temperature increased from 800 to $900^{\circ} \mathrm{C}$, which was caused by the enhanced Deacon reaction of chlorine with a content exceeding 1\% (Wikström et al., 1996), the I-TEQ values of the fly ash collected from the baghouse for the combustion

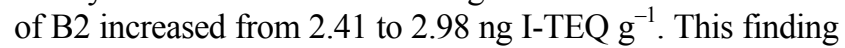
was consistent with the results obtained by Griffin (1986).

When the freeboard temperature increased from 800 to $900^{\circ} \mathrm{C}$, the $\mathrm{PCDD} / \mathrm{Fs}$ concentration of fly ash from the cyclone decreased from 0.136 to $0.025 \mathrm{ng} \mathrm{g}^{-1}$ (0.0037$0.0015 \mathrm{ng} \mathrm{I}^{-T E Q ~ \mathrm{~g}^{-1}}$ ) for the combustion of $\mathrm{B} 1$, and from $0.063-0.025 \mathrm{ng} \mathrm{g}^{-1}\left(0.0012-0.0015 \mathrm{ng} \mathrm{I-TEQ} \mathrm{g}^{-1}\right)$ for the combustion of $\mathrm{B} 2$. The ratio of PCDD to PCDF was approximately 1 , as shown in Table 4 . This result was also consistent with our expected observations. No de novo synthesis occurred at the bottom of the cyclone, and the increase in temperature resulted in more complete combustion, thus decreasing the PCDD/Fs concentration.

\section{Effect of Chlorine Content on PCDD/Fs in the Fly Ash Collected from the Baghouse}

Because the dioxin concentration of the fly ash from the cyclone was extremely low, our discussion focuses on the fly ash baghouse. The concentrations of PCDD/Fs in the fly ash collected from the baghouse were $22.60 \mathrm{ng} \mathrm{g}^{-1}$ and $2.13 \mathrm{ng}^{\mathrm{I}-T E Q ~ \mathrm{~g}^{-1}}$ after the combustion of B1, while those after the combustion of B2 were $28.41 \mathrm{ng} \mathrm{g}^{-1}$ and $2.41 \mathrm{ng}$ I-TEQ $\mathrm{g}^{-1}$. The results indicate that the formation of $\mathrm{PCDD} / \mathrm{Fs}$ increased with the chlorine content, which was consistent with our expectations.

Table 5 shows that the copper content of B1 and B2 was 265 and 324 ppm, respectively. The production of chlorine gas was low since the catalyst was insufficient, as shown in formula (2). Even with the combustion of a feeding material with high chlorine content, such as B2, there was no significant difference in the dioxin production in the case of either B1 or B2. To evaluate the role of particulate organic carbon in the formation of PCDD/PCDF in fly ash, Stieglitz et al. (1989) investigated the correlation between PCDD/Fs and $\mathrm{Cu}(\mathrm{II})$ by adding copper content of $0,0.08$, 0.24 , and $0.4 \%$, and their results showed that only small concentrations of PCDD (4.5 $\left.\mathrm{ng} \mathrm{g}^{-1}\right)$ and PCDF (22.6 $\left.\mathrm{ng} \mathrm{g}^{-1}\right)$ were produced without copper. The addition of $0.08 \% \mathrm{Cu}(\mathrm{II})$ promoted the formation of PCDD at $100 \mathrm{ng} \mathrm{g}^{-1}$, and PCDF at $760 \mathrm{ng} \mathrm{g}^{-1}$. An increase in the copper concentrations to $0.24 \%$ and $0.4 \%$ caused a significant increase in the $\mathrm{PCDD} / \mathrm{F}$ content. Mattila et al. (1992) found the addition of copper to lead to an increase in the formation of PCDD/Fs, especially PCDFs. According to the experimental data obtained from this study, the formation of dioxin is dependent not only on the chlorine content, but also on the copper content. A study conducted by Liu et al. (2019) had similar results. However, further study is required.

As the freeboard temperature increased from 800 to $900^{\circ} \mathrm{C}$, the $\mathrm{PCDD} / \mathrm{Fs}$ concentration of fly ash decreased

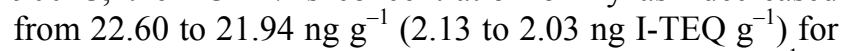
the combustion of $\mathrm{B} 1$ and increased from $28.41 \mathrm{ng} \mathrm{g}^{-1}$ to

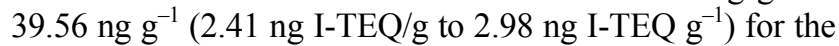
combustion of $\mathrm{B} 2$. The $\mathrm{PCDD} / \mathrm{Fs}$ concentration in the fly ash decreased with an increase in the freeboard temperature for the combustion of B1, but it increased with an increase in the freeboard temperature for combustion of B2.

Typically, an increase in temperature makes the combustion more complete and decreases the formation of dioxin. As the freeboard temperature is increased, the products of incomplete combustion (PICs) are reduced, resulting in a decline in the carbon source required for PCDD/Fs formation. The results of this test showed that the dioxin concentration in the fly ash from B2 increased as the freeboard temperature increased, which can be attributed to the release of the large amount of hydrogen chloride released into the furnace to increase the chlorine content beyond $1 \%$. As the temperature increases, the Deacon reaction also increases (Liu et al., 2000),

$$
2 \mathrm{HCl}+1 / 2 \mathrm{O}_{2} \stackrel{\mathrm{Cu}}{\longrightarrow} \mathrm{Cl}_{2}+\mathrm{H}_{2} \mathrm{O}
$$

Table 5. Copper content of the fly and bottom ash.

\begin{tabular}{llll}
\hline feeding material & $\mathrm{Cu}(\mathrm{ppm})$ in bottom ash & $\begin{array}{l}\mathrm{Cu}(\mathrm{ppm}) \text { in fly ash } \\
\left(\text { at } 800^{\circ} \mathrm{C}\right)\end{array}$ & $\begin{array}{l}\mathrm{Cu}(\mathrm{ppm}) \text { in fly ash } \\
\left(\text { at } 900^{\circ} \mathrm{C}\right)\end{array}$ \\
\hline $\mathrm{B} 1(\mathrm{Cl}=0.568 \%)$ & $\mathrm{ND}$ & 265 & 323 \\
$\mathrm{~B} 2(\mathrm{Cl}=1.136 \%)$ & $\mathrm{ND}$ & 324 & 346 \\
$\mathrm{C} 1(\mathrm{Cl}=0.568 \% \mathrm{~S}=0.4 \%)$ & $\mathrm{ND}$ & 359 & 366 \\
$\mathrm{C} 2(\mathrm{Cl}=0.568 \% \mathrm{~S}=0.4 \% \mathrm{Ca}=1.62 \%)$ & 61 & 400 & 371 \\
$\mathrm{C} 3(\mathrm{Cl}=1.136 \% \mathrm{~S}=0.8 \%)$ & 10 & 647 & 430 \\
$\mathrm{C} 4(\mathrm{Cl}=1.136 \% \mathrm{~S}=0.8 \% \mathrm{Ca}=3.25 \%)$ & 3 & 405 & 418 \\
$\mathrm{~S} 1(\mathrm{Cl}=0.568 \% \mathrm{~S}=0.8 \%)$ & 17 & 415 & 424 \\
$\mathrm{~S} 2(\mathrm{Cl}=0.568 \% \mathrm{~S}=0.8 \% \mathrm{Ca}=2.61 \%)$ & 20 & 374 & 395 \\
$\mathrm{~S} 3(\mathrm{Cl}=1.136 \% \mathrm{~S}=1.6 \%)$ & 33 & 360 & 380 \\
$\mathrm{~S} 4(\mathrm{Cl}=1.136 \% \mathrm{~S}=1.6 \% \mathrm{Ca}=5.23 \%)$ & 22 & 338 & 395 \\
\hline
\end{tabular}

ND: non-detected. 
and the enhancement of de novo synthesis caused by the increase in chlorine results in a significant increase in the production of PCDD/Fs. Liu et al. (2000) suggested that the optimum combustion condition for controlling molecular chlorine formation is to maintain the combustion temperatures in the freeboard at $650^{\circ} \mathrm{C}$. However, the temperature of the secondary combustion chamber in the incinerator is $850^{\circ} \mathrm{C}$, according to the regulations set forth by the Taiwan EPA.

\section{Effect of Sulfur Content on PCDD/Fs in the Fly Ash Collected from the Baghouse}

Table 2 shows that the $\mathrm{S} / \mathrm{Cl}$ ratios were 0.781 for $\mathrm{C} 1$ and $\mathrm{C} 3$, and 1.562 for $\mathrm{S} 1$ and S3, respectively. Table 4 shows that the I-TEQ values of the fly ash for the combustion of $\mathrm{C} 1$ and $\mathrm{C} 3$ at a freeboard temperature of $800^{\circ} \mathrm{C}$ were 2.46 and $3.08 \mathrm{ng} \mathrm{I}^{-T E Q ~} \mathrm{~g}^{-1}$, respectively. The I-TEQ values in the fly ash obtained from the combustion of S1 and S3 at a freeboard temperature of $800^{\circ} \mathrm{C}$ were 3.00 and $2.75 \mathrm{ng}$ ITEQ $\mathrm{g}^{-1}$, respectively, and the experimental data obtained from this test show that the effect of the $\mathrm{S} / \mathrm{Cl}$ ratio on the reduction of $\mathrm{PCDD} / \mathrm{Fs}$ was not obvious.

Ogawa et al. (1996) indicated that $\mathrm{SO}_{2}$ reacts with $\mathrm{Cu}(\mathrm{II})$ to reduce the ability of copper to catalyze the production of $\mathrm{Cl}_{2}$ while inhibiting the formation of PCDD/Fs.

$\mathrm{CuO}+\mathrm{SO}_{2}+1 / 2 \mathrm{O}_{2} \rightarrow \mathrm{CuSO}_{4}$

It is believed that pyrite may react with copper compounds, such as copper chloride and oxide, to form copper sulfate (Takaoka et al., 2005; Pekarek et al., 2007). The reduction in the number of copper ions also reduces the Deacon reaction, and the decrease in chlorine production reduces the formation of dioxin. The research by Goldin et al. (1992) demonstrated that the copper content in the fly ash from incinerating municipal solid waste can be as high as $0.17 \%$. In this study, we found that the inhibitory effect of sulfur was not as expected, which may be attributed to the low copper content in the feeding material. Further study is required to verify this.

As the freeboard temperature was increased from 800 to $900^{\circ} \mathrm{C}$, the I-TEQ values of the fly ash collected from the baghouse after the combustion of $\mathrm{C} 1, \mathrm{C} 3, \mathrm{~S} 1$, and $\mathrm{S} 3$ decreased from 2.46 to $2.44,3.08$ to $2.89,3.00$ to 2.74 , and

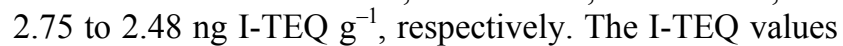
of the fly ash collected from the baghouse decreased with increases in the freeboard temperature. Griffin (1986) proposed a mechanism involving sulfur as an inhibitor of dioxin formation and suggested that $\mathrm{SO}_{2}$ is attacked by $\mathrm{Cl}_{2}$ to form $\mathrm{SO}_{3}$ and $\mathrm{HCl}$ in the presence of $\mathrm{H}_{2} \mathrm{O}$. Similar results were also obtained by Liu et al. (2000).

$\mathrm{Cl}_{2}+\mathrm{H}_{2} \mathrm{O}+\mathrm{SO}_{2} \rightarrow \mathrm{SO}_{3}+2 \mathrm{HCl}$

Fig. 3 shows the measured $\mathrm{SO}_{2}$ emissions and theoretical maximum $\mathrm{SO}_{2}$ values calculated using the data presented in Table 1. According to Fig. 3, the theoretical maximum $\mathrm{SO}_{2}$ concentration was much higher than the observed concentration. As the sulfur content increased, the theoretical calculated and experimental values of $\mathrm{SO}_{2}$ increased. The chlorine content of $\mathrm{C} 3$ was higher than that of $\mathrm{S} 1$, and the $\mathrm{SO}_{2}$ concentration of the flue gas from the combustion of $\mathrm{C} 3$ was lower than that of S1. This can be attributed to the consumption of $\mathrm{SO}_{2}$ as it reacted with chlorine, as shown in Eq. (4). According to the data shown in Table 6, as the freeboard temperature was increased from 800 to $900^{\circ} \mathrm{C}$, the concentration of $\mathrm{SO} 2$ in the flue gas from the combustion of C1, C3, S1, and S3 decreased from 47 to $24 \mathrm{ppm}, 146$ to $131 \mathrm{ppm}, 286$ to $229 \mathrm{ppm}$, and 695 to $618 \mathrm{ppm}$, respectively. This decrease in the $\mathrm{SO}_{2}$ emissions can be attributed to the consumption of $\mathrm{SO}_{2}$ by the reaction with $\mathrm{Cl}_{2}$, as shown in Eq. (4). The experimental data obtained in this study agreed with the phenomena indicating that sulfur can

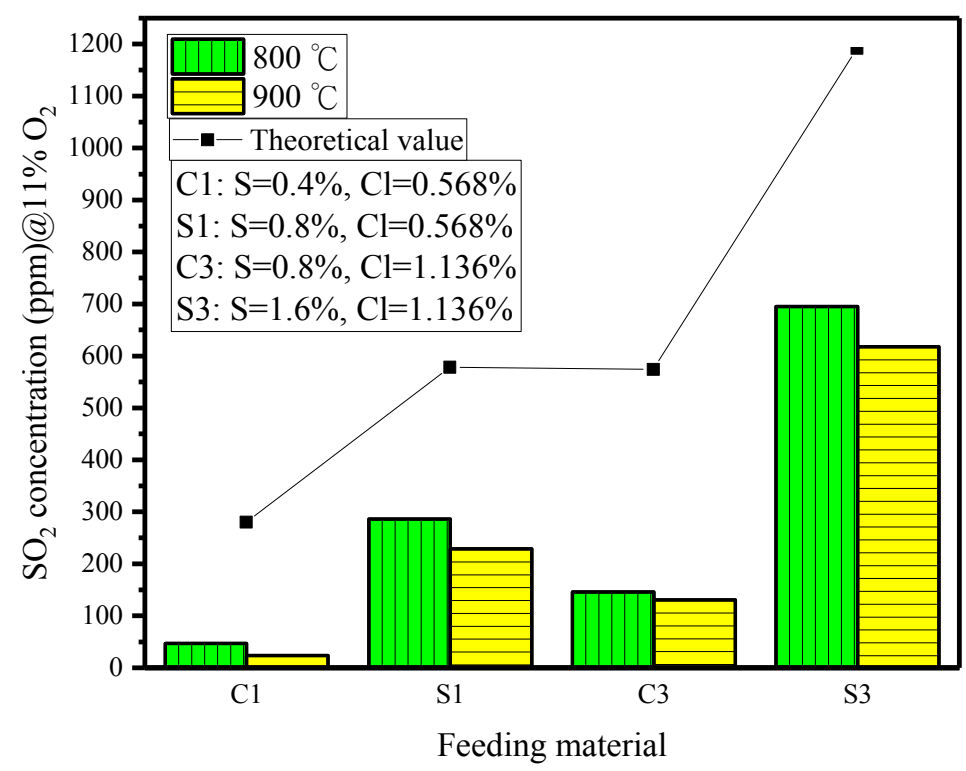

Fig. 3. $\mathrm{SO}_{2}$ emissions from the combustion of various feeding materials without the addition of calcium at various freeboard temperatures. 
Table 6. Flue gas emissions and combustion efficiencies of the various feeding materials.

\begin{tabular}{lllllllllll}
\hline & $\mathrm{B} 1$ & $\mathrm{~B} 2$ & $\mathrm{C} 1$ & $\mathrm{C} 2$ & $\mathrm{C} 3$ & $\mathrm{C} 4$ & $\mathrm{~S} 1$ & $\mathrm{~S} 2$ & $\mathrm{~S} 3$ & $\mathrm{~S} 4$ \\
\hline $800^{\circ} \mathrm{C}$ & & & & & & & & & & \\
$\mathrm{CO}(\mathrm{ppm})$ & 20 & 19 & 26 & 43 & 45 & 36 & 43 & 40 & 60 & 55 \\
$\mathrm{CO}_{2}$ (vol\%) & 9.0 & 9.1 & 8.9 & 8.9 & 8.8 & 8.9 & 9.1 & 9.0 & 8.9 & 9.3 \\
$\mathrm{SO}_{2}$ (ppm) & $\mathrm{ND}$ & $\mathrm{ND}$ & 47 & 14 & 146 & 25 & 286 & 17 & 695 & 50 \\
$\mathrm{Combustion}$ efficiency (\%) & 99.86 & 99.78 & 99.78 & 99.70 & 99.70 & 99.52 & 99.57 & 99.65 & 99.76 & 99.50 \\
$900^{\circ} \mathrm{C}$ & & & & & & & & & & \\
$\mathrm{CO}$ (ppm) & 11 & 6 & 7 & 9 & 22 & 9 & 10 & 9 & 18 & 23 \\
$\mathrm{CO}($ wt\%) & 8.8 & 8.9 & 8.8 & 8.8 & 8.6 & 8.7 & 8.8 & 8.8 & 8.6 & 9.1 \\
$\mathrm{SO}_{2}$ (ppm) & $\mathrm{ND}$ & $\mathrm{ND}$ & 24 & 7 & 131 & 20 & 229 & 12 & 618 & 45 \\
$\mathrm{Combustion} \mathrm{efficiency} \mathrm{( \% )}^{9}$ & 99.96 & 99.94 & 99.94 & 99.89 & 99.94 & 99.83 & 99.90 & 99.90 & 99.92 & 99.87 \\
\hline
\end{tabular}

ND: none detected.

All the pollutants were calibrated to residual oxygen at an $11 \%$ dry base.

inhibit the formation of dioxin at higher temperatures.

The lack of chlorine caused by the inhibition of $\mathrm{SO}_{2}$ is not conducive to the de novo reaction, and thus reduces the production of dioxin. It was expected that the formation of dioxin would decrease with increases in the freeboard temperature. When the freeboard temperature was increased from 800 to $900^{\circ} \mathrm{C}$, the I-TEQ values of the fly ash from the combustion of $\mathrm{C} 3$ and $\mathrm{S} 3$ decreased from 3.08 to 2.89 ng I-TEQ $\mathrm{g}^{-1}$ and 2.75 to $2.48 \mathrm{ng}^{\mathrm{I}-T E Q ~ \mathrm{~g}^{-1}}$, respectively. The inhibitory effect of sulfur with a higher $\mathrm{S} / \mathrm{Cl}$ ratio (S3) on dioxin formation was higher than that with a low $\mathrm{S} / \mathrm{Cl}$ ratio $(\mathrm{C} 3)$.

\section{Effect of Calcium Content on PCDD/Fs in the Fly Ash Collected from the Baghouse}

The results reported by Matsukata et al. (1996) indicated that the chlorination reaction of calcium oxide was inhibited, and the sulfurization reaction was enhanced when desulfurization and de-chlorination occurred simultaneously. Tagashira et al. (1999) conducted an experiment on desulfurization and de-chlorination at a ratio of $\mathrm{Ca} /(\mathrm{S}+$ $0.5 \mathrm{Cl})=2$, and their results demonstrated that the added calcium hydroxide can simultaneously adsorb hydrogen chloride and sulfur dioxides, and thus reduce dioxin production. Experimental data regarding the effects of calcium addition in the presence of both sulfur and chlorine on dioxin formation are still required. In this study, the effect of the simultaneous addition of sulfur and calcium on dioxin formation in fly ash was studied with a $\mathrm{Ca} /(\mathrm{S}+$ $0.5 \mathrm{Cl}$ ) ratio of 1.98 .

Table 2 shows the calcium content of $\mathrm{C} 2, \mathrm{C} 4, \mathrm{~S} 2$, and S4 was $1.62 \%, 3.25 \%, 2.61 \%$, and $5.23 \%$, respectively. Fig. 4 shows the emissions of $\mathrm{SO}_{2}$ with various calcium and chlorine contents added to the feeding material, where it can be seen that they were significantly reduced with the addition of a calcium compound, which was consistent with our expectations. When calcium and sulfur were added, desulfurization and dechlorination reactions occurred simultaneously. Lin and Chyang (2016) found that chlorination is significantly suppressed as chloride begins to vigorously react with $\mathrm{SO}_{2}$, leading to the indirect enhancement of sulfation and the re-release of $\mathrm{HCl}$ into the gas phase, as shown in Eq. (5).
$\mathrm{CaCl} \cdot \mathrm{H}_{2} \mathrm{O}+\mathrm{SO}_{2}+\mathrm{O}_{2}=\mathrm{CaSO}_{4}+\mathrm{HCl}$

At a freeboard temperature of $800^{\circ} \mathrm{C}$ and chlorine content below $1 \%$, the I-TEQ value of the fly ash from the combustion of $\mathrm{C} 2(\mathrm{Ca}=1.62)$ was higher than that of $\mathrm{C} 1$ $(\mathrm{Ca}=0)$, and that of the fly ash from the combustion of S2 $(\mathrm{Ca}=2.61)$ was higher than that of $\mathrm{S} 1(\mathrm{Ca}=0)$. For chlorine content higher than $1 \%$, the I-TEQ value of the fly ash from the combustion of $\mathrm{C} 4(\mathrm{Ca}=3.25 \%)$ was lower $(22 \%)$ than that of $\mathrm{C} 3(\mathrm{Ca}=0)$, and that of the fly ash from the combustion of $\mathrm{S} 4(\mathrm{Ca}=5.23 \%)$ was lower $(5 \%)$ than that of S3 $(\mathrm{Ca}=0)$. The results obtained in this study indicate that a calcium content of $3.25 \%$ or more inhibits the formation of dioxins, which agrees with the results of a study conducted by Xie et al. (2000). Qin et al. (2017) indicate that the increase of $\mathrm{CaO} / \mathrm{S}$ was beneficial for suppressing PAHs formation and capturing $\mathrm{SO}_{2}$. With the injection of more limestone into the combustor, it was expected that more hydrogen chloride would be captured by the limestone. It was then expected that the formation of PCDD/Fs would reduce remarkably. If the amount of calcium added is insufficient, dechlorination will be decreased, resulting in an increase in dioxin formation.

Fig. 5 shows the I-TEQ values of the fly ash collected from the baghouse from the combustion of various feeding materials at different freeboard temperatures. As the freeboard temperature was increased from 800 to $900^{\circ} \mathrm{C}$, the I-TEQ values of the fly ash for the combustion of $\mathrm{C} 2$ increased from 2.72 to 3.42 , and those of $\mathrm{C} 4, \mathrm{~S} 2$, and S4 increased from 2.41, 3.11, and 2.61 to 2.80, 3.38, and 2.79, respectively. High temperatures reduced the ability of calcium to adsorb HCL, resulting in an increase in dioxin formation. The results of Piao et al. (1998) indicate that the best temperature for hydrogen chloride removal is $600^{\circ} \mathrm{C}$, and a removal rate of $70 \%$ can even be obtained at temperatures higher than $900^{\circ} \mathrm{C}$. The results reported by Corella et al. (2008) showed that the reaction temperature for the $\mathrm{CaO}$ adsorbent should not exceed $772^{\circ} \mathrm{C}$. If the temperature exceeds $800^{\circ} \mathrm{C}$, which is above the melting point of the product, the activity of $\mathrm{CaO}$-based solids is very low.

When both calcium and sulfur were added to the feeding materials, desulfurization and dechlorination reactions 


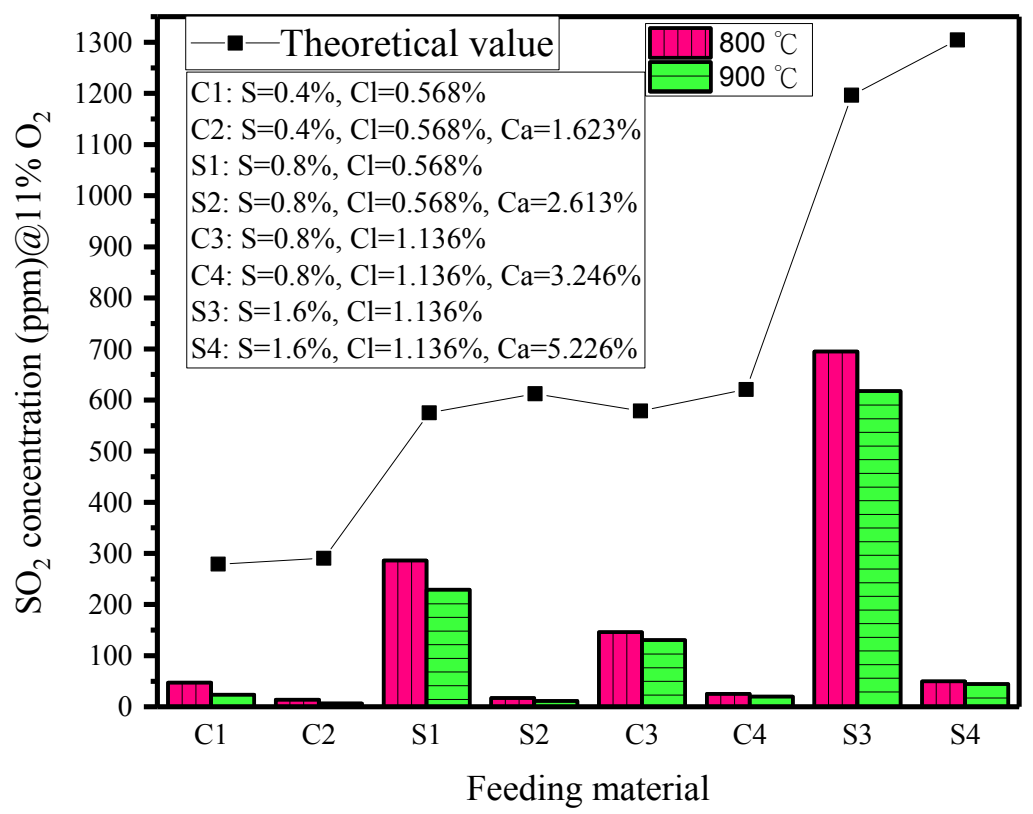

Fig. 4. $\mathrm{SO}_{2}$ emissions from the combustion of various feeding materials with/without the addition of calcium at various freeboard temperatures.

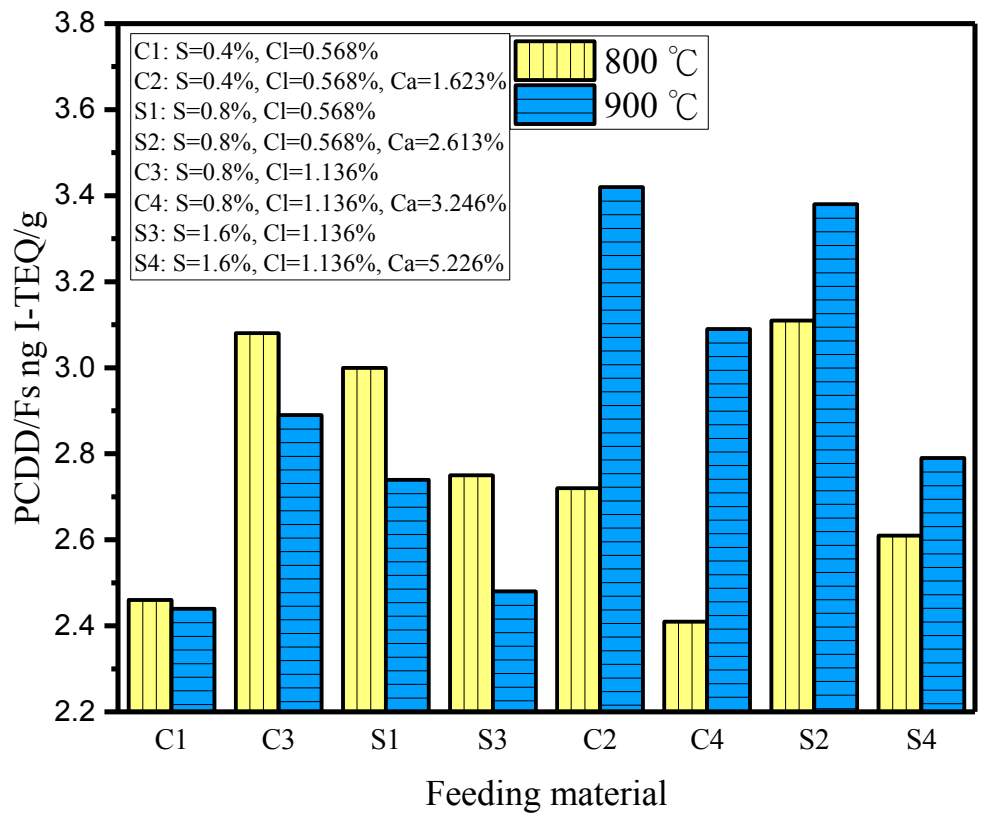

Fig. 5. I-TEQ values in the fly ash from the combustion of various feeding materials at different freeboard temperatures.

occurred simultaneously. Owing to the competition between desulfurization and dechlorination, it was expected that $\mathrm{SO}_{2}$ would be consumed by reacting with $\mathrm{CaO}$ to form $\mathrm{CaSO}_{4}$, thus reducing their ability to inhibit dioxin formation. The experimental data indicated that the dioxin content of fly ash from the combustion of a feeding material with a sufficient calcium content could still be reduced. As the freeboard temperature was increased from 800 to $900^{\circ} \mathrm{C}$, the ability of calcium to adsorb $\mathrm{HCl}$ decreased, resulting in an increase in the dioxin content of the fly ash collected from the baghouse. Owing to the inhibitory effects of sulfur, the I-TEQ values for C4 and S4 were lower than those of $\mathrm{B} 2$, which did not receive calcium and sulfur.

\section{Profiles of the Homologs and Congeners of PCDD/Fs in the Fly Ash Collected from the Baghouse}

Fig. 6 shows the congener profiles of the seventeen PCDD/Fs. Each congener was normalized by the sum of the seventeen PCDD/Fs, and the profiles obtained in each experiment were similar. Fig. 6(a) shows that the most prevalent congeners in the ash were $1,2,3,4,6,7,8-\mathrm{HpCDF}$ (19.7-23.4\%), OCDD (12.9-17.3\%), and OCDF (9.1- 
(a)

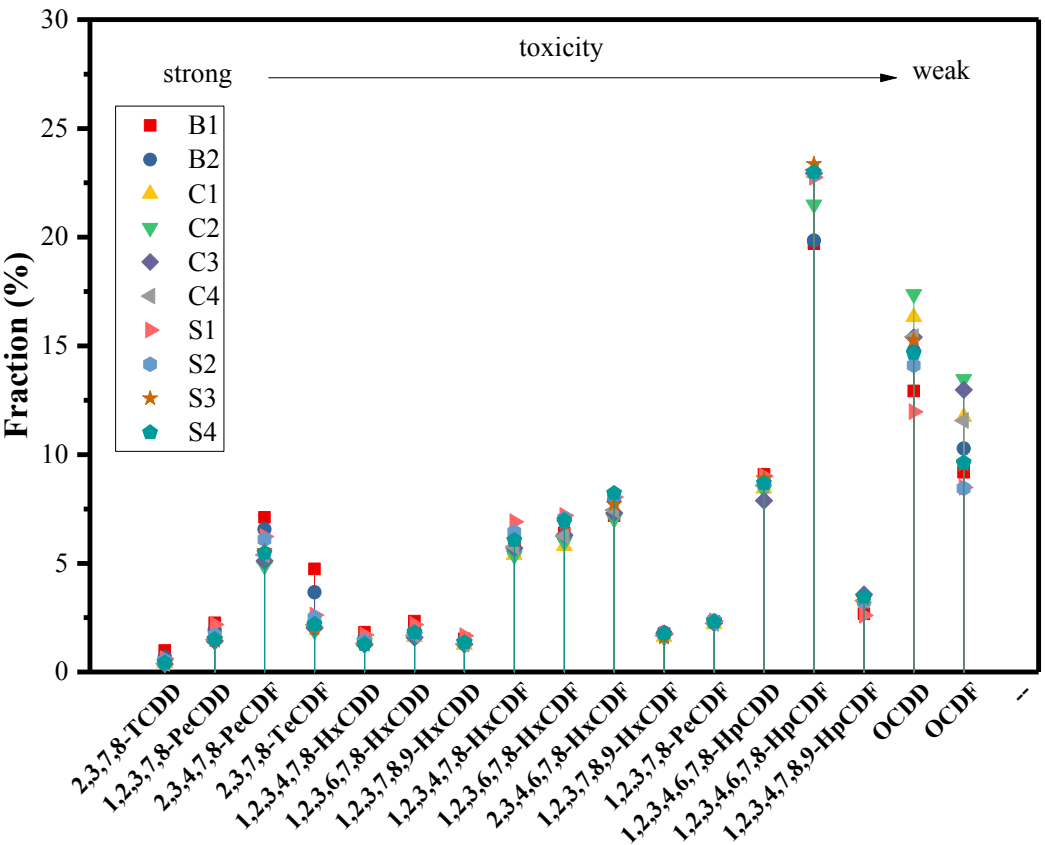

(b)

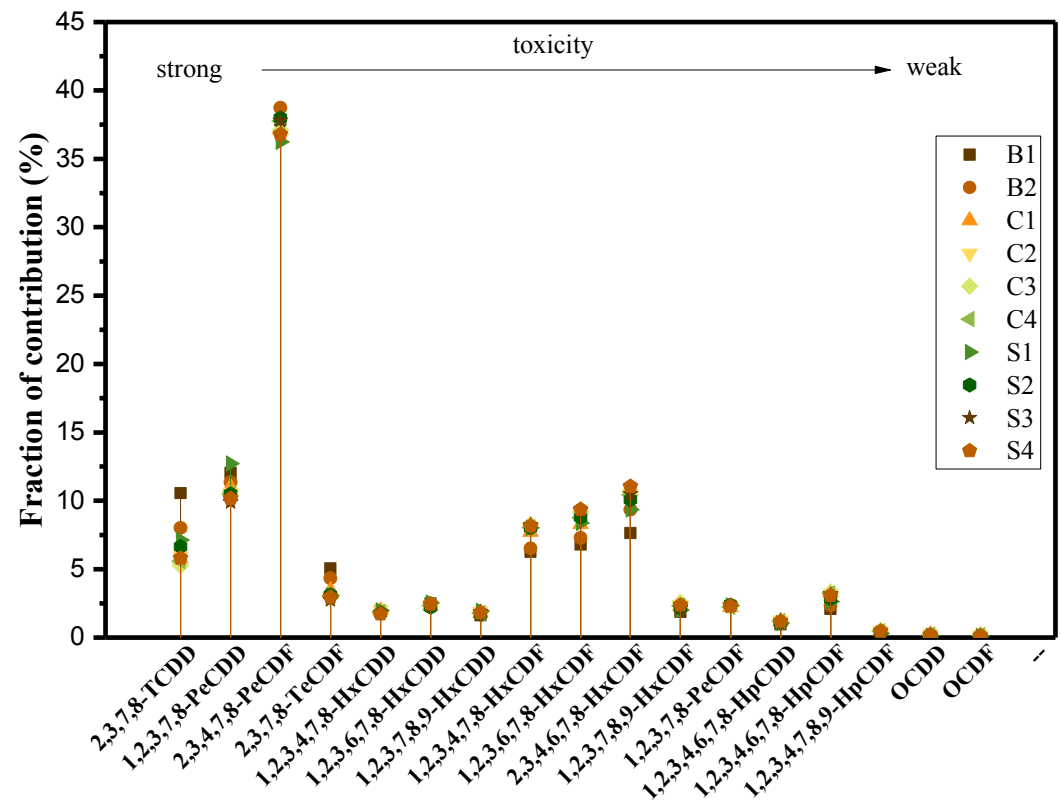

Fig. 6. Congeners of the 2,3,7,8-substituted PCDD/Fs of the fly ash obtained from the combustion of various feeding materials at a freeboard temperature of $800^{\circ} \mathrm{C}$. (a) Fraction of PCDD/Fs and (b) Fraction of contribution to I-TEQ values.

13.5\%). HxCDF and HpCDF were the two dominant homologs, results which were similar to those of Liu et al. (2017). From the viewpoint of the contribution to the total I-TEQ values (as shown in Fig. 6(b)), the greatest contributor was 2,3,4,7,8-PeCDF (36.72-38.66\%), which was a similar finding to that of other researchers (Han et al., 2017; Hsieh et al., 2018; Lin et al., 2018; Zhan et al., 2018).

The results of this study were compared in Fig. 7 with those obtained from previous studies (Cains et al., 1997; Shin and Chang, 1999; Moon et al., 2002; Hsi et al., 2007; Lundin and Marklund, 2008; Chang et al., 2011). The figure shows the distribution of the PCDD/Fs homologs from the combustion of various feeding materials. According to the data shown in Fig. 7, the distribution of the PCDD homologs was dominated by OCDD, while the dominant contributors to the PCDF distribution varied. Other than the combustion of fuels, this may have been caused by the injection of activated carbon into the flue gas for the purpose of incineration. In the absence of activated carbon, low-chlorinated PCDD and PCDF were not easily adsorbed by the fly ash in the baghouse, resulting in a high chloride bond distribution in PCDD and PCDF. After the injection of activated carbon, the concentration of low-chlorine bonds adsorbed on the activated carbon increased. The distribution of the PCDF homologs changed significantly due to de novo synthesis (PCDF > PCDD) (Vermeulen et al., 2014). 
(a)

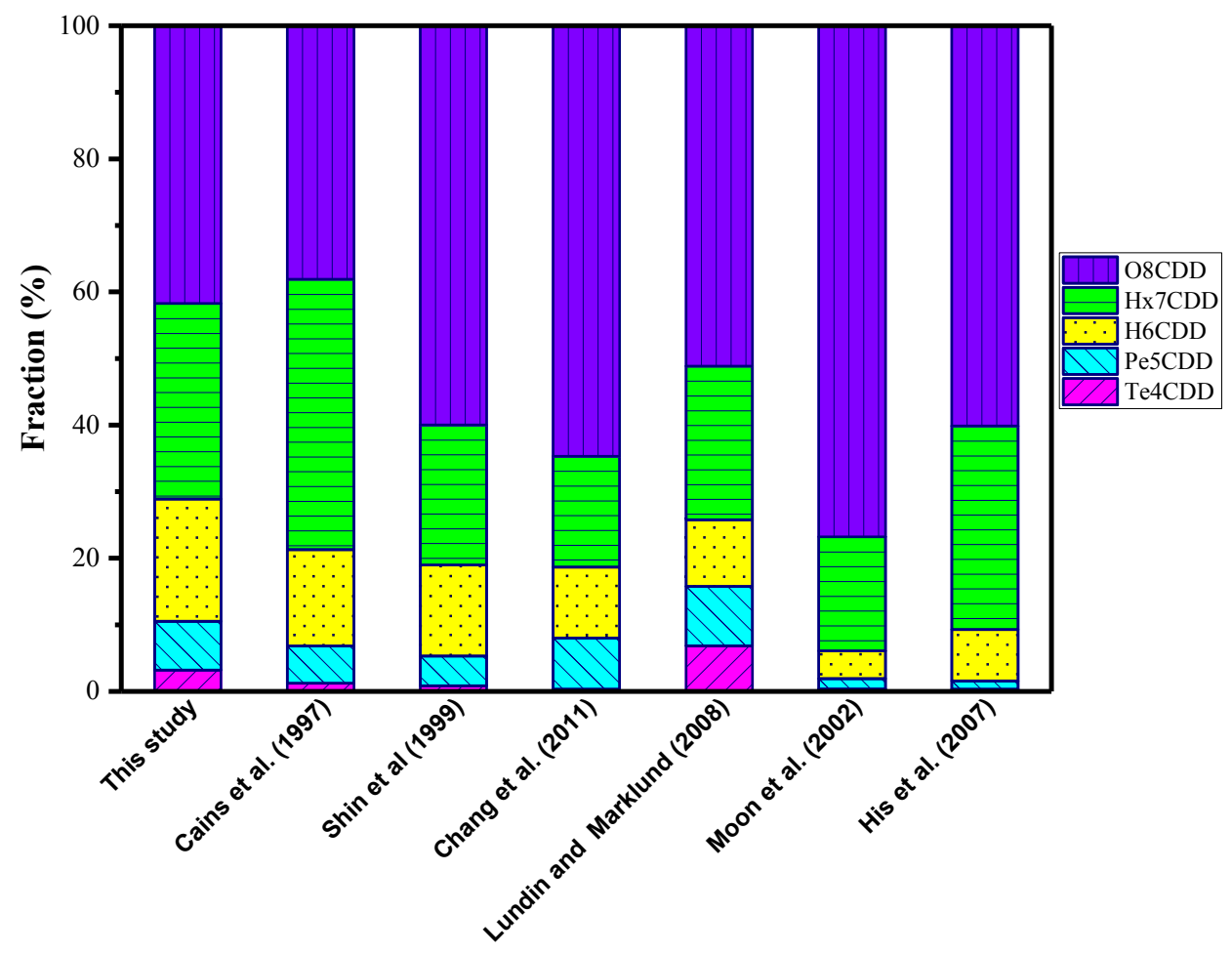

(b)

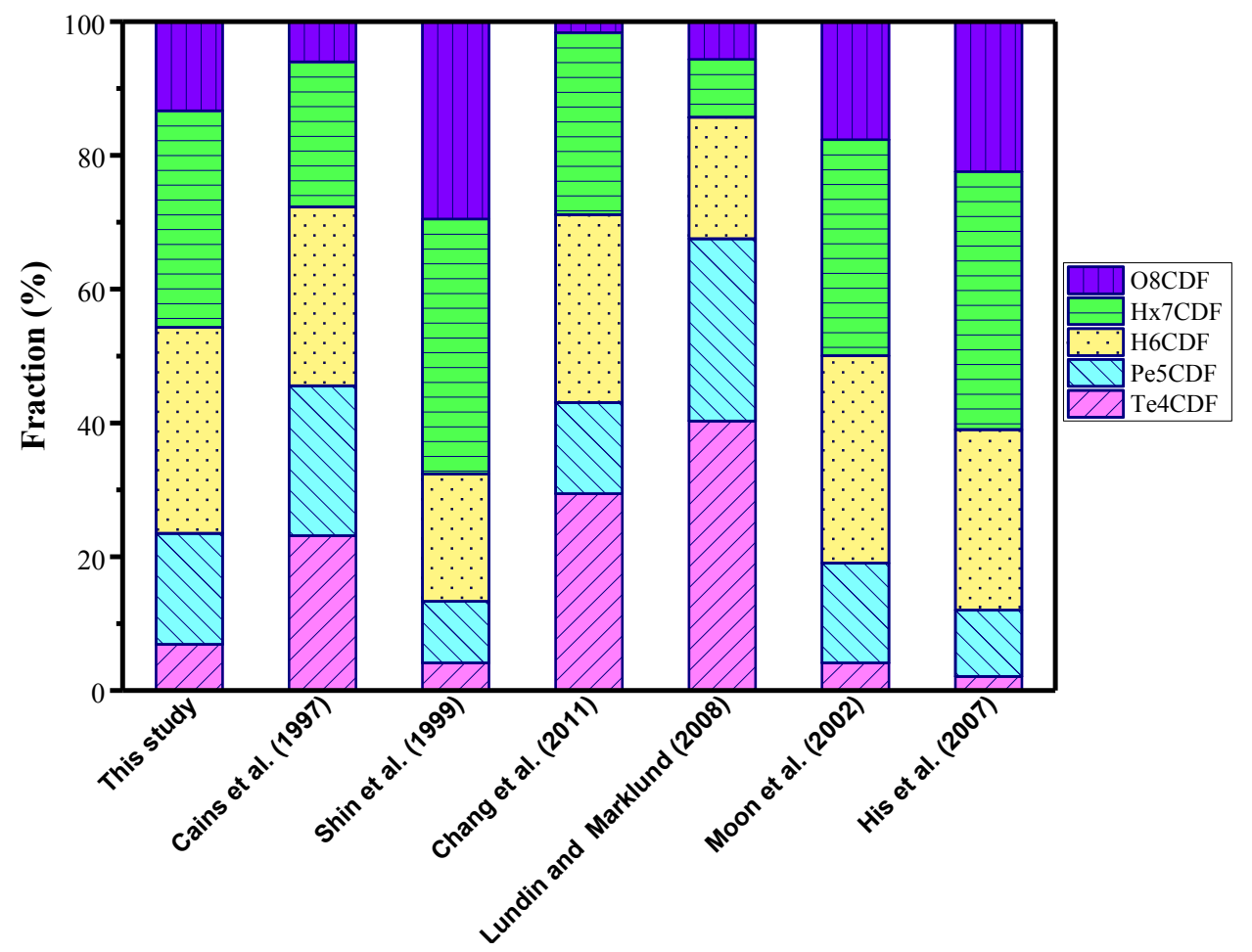

Fig. 7. Comparison of the distribution of PCDD/F homologs in fly ash based on the results of various studies. (a) PCDD and (b) PCDF.

Some researchers have reported a linear correlation between the 2,3,4,7,8-PeCDF concentration and I-TEQ values (Fiedler et al., 2000; Kato and Urano, 2001; Iino et al., 2003). A positive correlation was observed in this study, as shown in Fig. 8, which was similar to the result of Kato and Urano (2001).

\section{Influence of Flue Gas Emissions and Residual Carbon on PCDD/Fs}

As the combustion temperature of the freeboard was increased, it was expected that the combustion efficiency would increase, resulting in lower carbon monoxide emissions, as shown in Table 6 . The results of a regression 


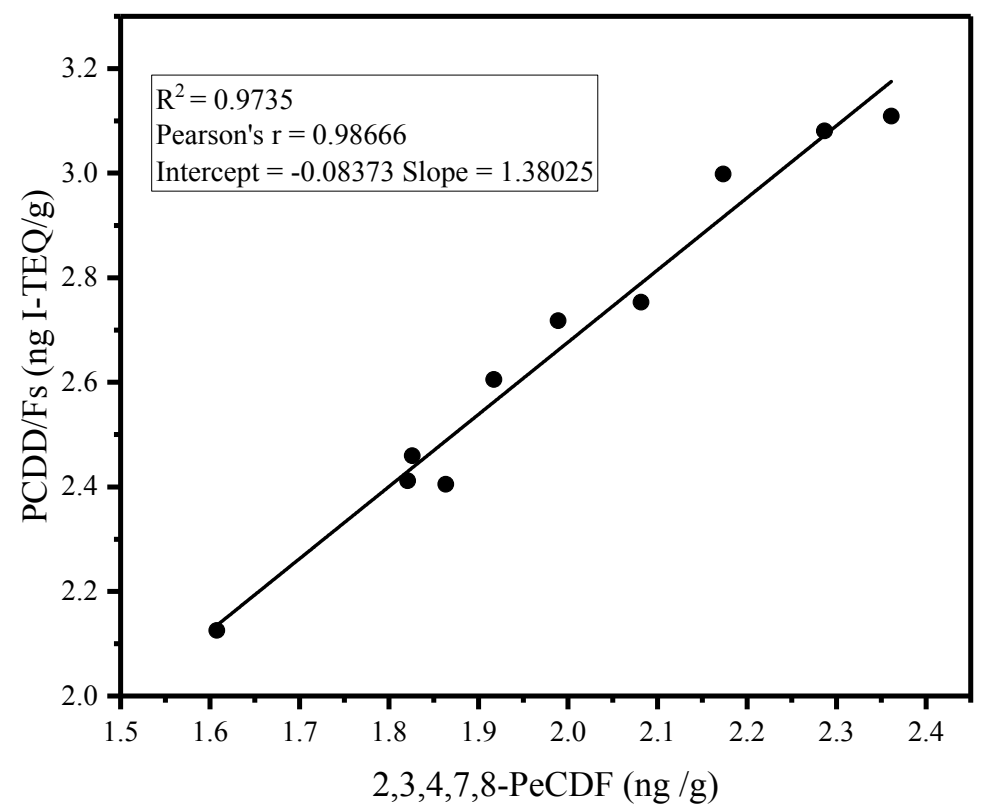

Fig. 8. Relationship between the concentration of $2,3,4,7,8-\mathrm{PeCDF}$ and the I-TEQ values.

analysis (not shown in this report), carbon monoxide and dioxide did not correlate with the concentrations of PCDD/Fs in the fly ash. Lenoir et al. (1991) observed no relationship between $\mathrm{PCDD} / \mathrm{Fs}$ and $\mathrm{CO}$ in a pilot-scale fluidized-bed incinerator under normal operating conditions with $\mathrm{CO}$ levels ranging from $2-210 \mathrm{mg} \mathrm{m}^{-3}$. Yan et al. (2006) also demonstrated that there is no direct correlation between the PCDD/Fs levels and CO.

Brna and Kilgroe (1992) suggested that reliable predictions can be made for CO concentrations above 150-200 ppm, but, below this range, the discrepancy between observed and predicted values is very large. Kaune et al. (1994) indicated that the correlation between $\mathrm{PCDD} / \mathrm{Fs}$ and $\mathrm{CO}$ is sustained under poor combustion conditions. As soon as the incinerator operating conditions are optimized, other factors that affect the emission of PCDD/Fs become more important. From the data shown in Table 6 , the $\mathrm{CO}$ emissions in this study were very low, at $<100 \mathrm{ppm}$. This may be a reason for the lack of a correlation between dioxin and $\mathrm{CO}$ emissions.

\section{CONCLUSIONS}

The main purposes of this study were to investigate the effects of sulfur and calcium content on the concentration of dioxin in fly ash from FBC. The conclusions are as follows:

1. The concentration of dioxins in the fly ash collected from the cyclone $\left(0.025-0.284 \mathrm{ng} \mathrm{g}^{-1}\right)$ was much lower than that of the fly ash collected from the baghouse (21.937-48.722 $\mathrm{ng} \mathrm{g}^{-1}$ ), and lower than the standard value of $1 \mathrm{ng} / \mathrm{g}$. De novo synthesis did not occur at the bottom of the cyclone, and dioxin was mainly derived from precursors. The PCDD/Fs of the fly ash from the baghouse were mainly formed through de novo synthesis.

2. The increase in chlorine content from 0.568 to $1.136 \mathrm{wt} \%$ resulted in the increase $27.4 \%$ of $\mathrm{PCDD} / \mathrm{Fs}$ in the fly ash collected from the baghouse. From the data obtained from this study, we can state that the amount of dioxins formed in the baghouse is dependent not only on the chlorine content of the feeding material, but also on the copper content.

3. The inhibitory effect of sulfur on dioxin formation is not clear and can be attributed to the lack of copper (average $387 \mathrm{ppm}$ ), as it did not result in a significant decrease in the formation of dioxins.

4. When both calcium and sulfur were added to the feeding materials, desulfurization inhibited de-chlorination, and a specific amount of calcium was required to reduce the formation of dioxins in the fly ash. The adsorption ability of calcium was decreased as the temperature increased from 800 to $900^{\circ} \mathrm{C}$, resulting in an increase in the dioxin content (average 10\%) of the fly ash collected from the baghouse.

5. From the viewpoint of the contribution of I-TEQ $\mathrm{g}^{-1}$, the dominant contributor was $2,3,4,7,8-\mathrm{PeCDF}$ since a positive relationship $\left(\mathrm{R}^{2}=0.9735\right)$ between the $2,3,4,7,8$ PeCDF concentration and the I-TEQ values was obtained in this study.

6. In this study, no relationship was observed between the $\mathrm{CO}$ emissions and PCDD/Fs concentrations in the fly ash from the baghouse. This was attributed to the narrow range and low emissions of $\mathrm{CO}$.

\section{REFERENCES}

Anthony, E., Jia, L. and Granatstein, D. (2001). Dioxin and furan formation in FBC boilers. Environ. Sci. Technol. 35: 3002-3007.

Bie, R., Li, S. and Yang, L. (2005). Reaction mechanism of $\mathrm{CaO}$ with $\mathrm{HCl}$ in incineration of wastewater in fluidized bed. Chem. Eng. Sci. 60: 609-616. 
Brna, T.G. and Kilgroe, J.D. (1992). Polychlorinated dibenzo- $p$-dioxins and dibenzofurans: Removal from flue gas and distribution in ash/residue of a refuse-derived fuel combustor. Chemosphere 25: 1381-1386.

Buekens, A. and Huang, H. (1998). Comparative evaluation of techniques for controlling the formation and emission of chlorinated dioxins/furans in municipal waste incineration. J. Hazard. Mater. 62: 1-33.

Cains, P.W., Mccausland, L.J., Fernandes, A.R. and Dyke, P. (1997). Polychlorinated dibenzo- $p$-dioxins and dibenzofurans formation in incineration: Effects of fly ash and carbon source. Environ. Sci. Technol. 31: 776785.

Chang, M.B. and Huang, T.F. (1999). Dioxin contents in fly ash from large-scale MSW incinerators in Taiwan. Chemosphere 39: 2671-2680.

Chang, M.B., Cheng, Y.C. and Chi, K.H. (2006). Reducing $\mathrm{PCDD} / \mathrm{F}$ formation by adding sulfur as inhibitor in waste incineration processes. Sci. Total Environ. 366: 456-465.

Chang, Y.M., Fan, W.P., Dai, W.C., Hsi, H.C., Wu, C.H. and Chen, C.H. (2011). Characteristics of PCDD/F content in fly ash discharged from municipal solid waste incinerators. J. Hazard. Mater. 192: 521-529.

Chi, K.H., Chang, S.H. and Chang, M.B. (2008). Reduction of dioxin-like compound emissions from a Waelz plant with adsorbent injection and a dual baghouse filter system. Environ. Sci. Technol. 42: 2111-2117.

Chiang, B.C., Wey, M.Y. and Yang, W.Y. (2000). Control of Incinerator organics by fluidized bed activated carbon adsorber. J. Environ. Eng. 126: 985-992.

Chyang, C.S., Han, Y.L., Wu, L.W., Wan, H.P., Lee, H.T. and Chang, Y.H. (2010). An investigation on pollutant emissions from co-firing of RDF and coal. Waste Manage. 30: 1334-1340.

Corella, J., Toledo, J.M. and Molina, G. (2008). Performance of $\mathrm{CaO}$ and $\mathrm{MgO}$ for the hot gas clean up in gasification of a chlorine-containing (RDF) feedstock. Bioresour. Technol. 99: 7539-7544.

Cui, Y.Y., Yang, G.H., Xiao, G.H., Zhou, J.H., Ding, G.Z. and Pan, X.J. (2017). Adsorption of dioxin by bag filter+ powdered activated carbon. Water Air Soil Pollut. 228: 160 .

Cunliffe, A.M. and Williams, P.T. (2009). De-novo formation of dioxins and furans and the memory effect in waste incineration flue gases. Waste Manag 29: 739748.

Fiedler, H., Lau, C. and Eduljee, G. (2000). Statistical analysis of patterns of PCDDs and PCDFs in stack emission samples and identification of a marker congener. Waste Manage. Res. 18: 283-292.

Frankenhaeuser, M., Manninen, H., Kojo, I., Ruuskanen, J., Vartiainen, T., Vesterinen, R. and Virkki, J. (1993). Organic emissions from co-combustion of mixed plastics with coal in a bubbling fluidized bed boiler. Chemosphere 27: 309-316.

Goldin, A., Bigelow, C. and Veneman, P.L. (1992). Concentrations of metals in ash from municipal solid waste combusters. Chemosphere 24: 271-280.
Griffin, R.D. (1986). A new theory of dioxin formation in municipal solid waste combustion. Chemosphere 15: 1987-1990.

Gullett, B.K., Bruce, K.R. and Beach, L.O. (1992a). Effect of sulfur dioxide on the formation mechanism of polychlorinated dibenzodioxin and dibenzofuran in municipal waste combustors. Environ. Sci. Technol. 26: 1938-1943.

Gullett, B.K., Bruce, K.R., Beach, L.O. and Drago, A.M. (1992b). Mechanistic steps in the production of PCDD and PCDF during waste combustion. Chemosphere 25: 1387-1392.

Hajizadeh, Y., Onwudili, J.A. and Williams, P.T. (2012). Effects of gaseous $\mathrm{NH}_{3}$ and $\mathrm{SO}_{2}$ on the concentration profiles of $\mathrm{PCDD} / \mathrm{F}$ in flyash under post-combustion zone conditions. Waste Manage. 32: 1378-1386.

Halonen, I., Tarhanen, J., Kopsa, T., Palonen, J., Vilokki, H. and Ruuskanen, J. (1993). Formation of polychlorinated dioxins and dibenzofurans in incineration of refuse derived fuel and biosludge. Chemosphere 26: 1869-1880.

Han, Y., Liu, W., Li, H., Lei, R., Gao, L., Su, G. and Liu, G. (2017). Gas-particle partitioning of polychlorinated dibenzo- $p$-dioxins, dibenzofurans, and biphenyls in flue gases from municipal solid waste incinerators. Aerosol Air Qual. Res. 17: 2847-2857.

Hatanaka, T., Imagawa, T. and Takeuchi, M. (2000). Formation of PCDD/Fs in artificial solid waste incineration in a laboratory-scale fluidised-bed reactor: Influence of contents and forms of chlorine sources in high-temperature combustion. Environ. Sci. Technol. 34: 3920-3924.

Hsi, H.C., Wang, L.C. and Yu, T.H. (2007). Effects of injected activated carbon and solidification treatment on the leachability of polychlorinated dibenzo- $p$-dioxins and dibenzofurans from air pollution control residues of municipal waste incineration. Chemosphere 67: 13941402.

Hsieh, Y.K., Chen, W.S., Zhu, J. and Huang, Q. (2018). Characterization of polychlorinated dibenzo- $p$-dioxins and dibenzofurans of the flue gases, fly ash and bottom ash in a municipal solid waste incinerator. Aerosol Air Qual. Res. 18: 421-432.

Huang, H. and Buekens, A. (1995). On the mechanisms of dioxin formation in combustion processes. Chemosphere 31: 4099-4117.

Hung, N.T., Ting, H.W. and Chi, K.H. (2018). Evaluation of the relative health risk impact of atmospheric PCDD/Fs in $\mathrm{PM}_{2.5}$ in Taiwan. Aerosol Air Qual. Res. 18: 2591-2599.

Hung, P.C., Lo, W.C., Chi, K.H., Chang, S.H. and Chang, M.B. (2011). Reduction of dioxin emission by a multilayer reactor with bead-shaped activated carbon in simulated gas stream and real flue gas of a sinter plant. Chemosphere 82: 72-77.

Iino, F., Takasuga, T., Touati, A. and Gullett, B.K. (2003). Correlations between homologue concentrations of $\mathrm{PCDD} / \mathrm{Fs}$ and toxic equivalency values in laboratory-, package boiler-, and field-scale incinerators. Waste Manage. 23: 729-736.

Kato, M. and Urano, K. (2001). Convenient substitute 
indices to toxic equivalent quantity for controlling and monitoring dioxins in stack gas from waste incineration facilities. Waste Manage. 21: 55-62.

Kaune, A., Lenoir, D., Nikolai, U. and Kettrup, A. (1994). Estimating concentrations of polychlorinated dibenzo- $p$ dioxins and dibenzofurans in the stack gas of a hazardous waste incinerator from concentrations of chlorinated benzenes and biphenyls. Chemosphere 29: 2083-2096.

Ke, S., Jianhua, Y., Xiaodong, L., Shengyong, L., Yinglei, W. and Muxing, F. (2010). Inhibition of de novo synthesis of $\mathrm{PCDD} / \mathrm{Fs}$ by $\mathrm{SO}_{2}$ in a model system. Chemosphere 78: 1230-1235.

Kobyashi, N., Itaya, Y., Piao, G., Mori, S., Kondo, M., Hamai, M. and Yamaguchi, M. (2005). The behavior of flue gas from RDF combustion in a fluidized bed. Powder Technol. 151: 87-95.

Lawrence, A. and $\mathrm{Bu}$, J. (2000). Reactions between Cabased solids and gases representative of those found in a fluidized-bed incinerator. Chem. Eng. Sci. 55: 61296137.

Lenoir, D., Kaune, A., Hutzinger, O., Mützenich, G. and Horch, K. (1991). Influence of operating parameters and fuel type on $\mathrm{PCDD} / \mathrm{F}$ emissions from a fluidized bed incinerator. Chemosphere 23: 1491-1500.

Li, Y., Wang, H., Jiang, L., Zhang, W., Li, R. and Chi, Y. (2015). $\mathrm{HCl}$ and PCDD/Fs emission characteristics from incineration of source-classified combustible solid waste in fluidized bed. RSC Adv. 5: 67866-67873.

Lin, G.M. and Chyang, C.S. (2016). Simultaneous $\mathrm{HCl} / \mathrm{SO}_{2}$ capture by calcined limestone from hot gases. Energy Fuels 30: 10696-10704.

Lin, W.Y., Wang, L.C., Wang, Y.F., Li, H.W. and ChangChien, G.P. (2008). Removal characteristics of PCDD/Fs by the dual bag filter system of a fly ash treatment plant. J. Hazard. Mater. 153: 1015-1022.

Lin, X., Zhan, M., Yan, M., Dai, A., Wu, H., Li, X., Chen, T., Lu, S. and Yan, J. (2015). Suppression of dioxins in waste incinerator emissions by recirculating $\mathrm{SO}_{2}$. Chemosphere 133: 75-81.

Lin, X., Ji, L., Zhan, M., Wang, L., Chen, T., Lu, S., Li, X. and Yan, J. (2018). Suppression of PCDD/Fs by raw meal in cement kilns. Aerosol Air Qual. Res. 18: 10321043.

Lindbauer, R.L., Wurst, F. and Prey, T. (1992). Combustion dioxin suppression in municipal solid waste incineration with sulfur additives. Chemosphere 25: 1409-1414.

Lindbauer, R.L., Wurst, F. and Prey, T. (1993). PCDD/F emission control by sulphur addition - New results with high $-\mathrm{S}$ lignite, $\mathrm{SO}_{2}$ and $\mathrm{SO}_{3}$. Organohalogen Compd. 12: $35-38$.

Liu, H.Q., Liu, F., Wei, G.X., Zhang, R. and Zhu, Y.W. (2017). Effects of surfactants on the removal of carbonaceous matter and dioxins from weathered incineration fly ash. Aerosol Air Qual. Res. 17: 23382347.

Liu, H.Q., Zeng, T.T., Wei, G.X., Zhang, R., Liu, F. and Wang, H. (2019). Comparison of dioxin destruction in the fly ash and froths under microwave. Aerosol Air Qual. Res. 19: 925-936.

Liu, K., Pan, W.P. and Riley, J.T. (2000). A study of chlorine behavior in a simulated fluidized bed combustion system. Fuel 79: 1115-1124.

Lundin, L. and Marklund, S. (2007). Thermal degradation of PCDD/F, PCB and $\mathrm{HCB}$ in municipal solid waste ash. Chemosphere 67: 474-481.

Lundin, L. and Marklund, S. (2008). Distribution of mono to octa-chlorinated PCDD/Fs in fly ash from a municipal solid-waste incinerator. Environ. Sci. Technol. 42: 1245-1250.

Ma, H., Du, N., Lin, X., Liu, C., Zhang, J. and Miao, Z. (2018). Inhibition of element sulfur and calcium oxide on the formation of PCDD/Fs during co-combustion experiment of municipal solid waste. Sci. Total Environ. 633: 1263-1271.

Matsukata, M., Takeda, K., Miyatani, T. and Ueyama, K. (1996). Simultaneous chlorination and sulphation of calcined limestone. Chem. Eng. Sci. 51: 2529-2534.

Mattila, H., Virtanen, T., Vartiainen, T. and Ruuskanen, J. (1992). Emissions of polychlorinated dibenzo-p-dioxins and dibenzofurans in flue gas from co-combustion of mixed plastics with coal and bark. Chemosphere 25: 1599-1609.

Milligan, M.S. and Altwicker, E. (1993). The relationship between de novo synthesis of polychlorinated dibenzo$p$-dioxins and dibenzofurans and low-temperature carbon gasification in fly ash. Environ. Sci. Technol. 27: 15951601.

Moon, M.H., Kang, D., Lim, H., Oh, J.E. and Chang, Y.S. (2002). Continuous fractionation of fly ash particles by SPLIT for the investigation of PCDD/Fs levels in different sizes of insoluble particles. Environ. Sci. Technol. 36: 4416-4423.

Ogawa, H., Orita, N., Horaguchi, M., Suzuki, T., Okada, M. and Yasuda, S. (1996). Dioxin reduction by sulfur component addition. Chemosphere 32: 151-157.

Olie, K., Vermeulen, P. and Hutzinger, O. (1977). Chlorodibenzo- $p$-dioxins and chlorodibenzofurans are trace components of fly ash and flue gas of some municipal incinerators in The Netherlands. Chemosphere 6: 455-459.

Pekarek, V., Punčochář, M., Bureš, M., Grabic, R. and Fišerová, E. (2007). Effects of sulfur dioxide, hydrogen peroxide and sulfuric acid on the de novo synthesis of $\mathrm{PCDD} / \mathrm{F}$ and PCB under model laboratory conditions. Chemosphere 66: 1947-1954.

Piao, G., Aono, S., Mori, S., Deguchi, S., Fujima, Y., Kondoh, M. and Yamaguchi, M. (1998). Combustion of refuse derived fuel in a fluidized bed. Waste Manage. 18: 509-512.

Preto, F., McCleave, R., McLaughlin, D. and Wang, J. (2005). Dioxins/furans emissions from fluidized bed combustion of salt-laden hog fuel. Chemosphere 58: 935-941.

Qin, L.B., Han, J., Chen, W.S., Wang, G.G., Luo, G.Q. and Yao, H. (2017). Simultaneous removal of $\mathrm{SO}_{2}$ and PAHs by adding calcium-based additives during sewage 
sludge incineration in a fluidized bed incinerator. $J$. Mater. Cycles Waste Manage. 19: 1061-1068.

Raghunathan, K. and Gullett, B.K. (1996). Role of sulfur in reducing PCDD and PCDF formation. Environ. Sci. Technol. 30: 1827-1834.

Ruuskanen, J., Vartiainen, T., Kojo, I., Manninen, H., Oksanen, J. and Frankenhaeuser, M. (1994). Formation of polychlorinated dibenzo- $p$-dioxins and dibenzofurans in co-combustion of mixed plastics with coal: Exploratory principal component analysis. Chemosphere 28: 19891999.

Ryan, S.P., Li, X.D., Gullett, B.K., Lee, C., Clayton, M. and Touati, A. (2006). Experimental study on the effect of $\mathrm{SO}_{2}$ on $\mathrm{PCDD} / \mathrm{F}$ emissions: determination of the importance of gas-phase versus solid-phase reactions in PCDD/F formation. Environ. Sci. Technol. 40: 70407047.

Shin, K.J. and Chang, Y.S. (1999). Characterization of polychlorinated dibenzo- $p$-dioxins, dibenzofurans, biphenyls, and heavy metals in fly ash produced from korean municipal solid waste incinerators. Chemosphere 38: 2655-2666.

Song, G.J., Kim, S.H., Seo, Y.C. and Kim, S.C. (2008). Dechlorination and destruction of PCDDs/PCDFs in fly ashes from municipal solid waste incinerators by low temperature thermal treatment. Chemosphere 71: 248257.

Stanmore, B. (2004). The formation of dioxins in combustion systems. Combust. Flame 136: 398-427.

Stieglitz, L., Zwick, G., Beck, J., Roth, W. and Vogg, H. (1989). On the de-novo synthesis of PCDD/PCDF on fly ash of municipal waste incinerators. Chemosphere 18: 1219-1226.

Stieglitz, L., Vogg, H., Bautz, H., Beck, J. and Zwick, G. (1990). The effects of sulfur dioxide on de novo synthesis of PCDD/PCDF on fly ash. Organohalogen Compd. 3: 175-177.

Stieglitz, L., Vogg, H., Zwick, G., Beck, J. and Bautz, H. (1991). On formation conditions of organohalogen compounds from particulate carbon of fly ash. Chemosphere 23: 1255-1264.

Tagashira, K., Torii, I., Myouyou, K., Takeda, K., Mizuko, T. and Tokushita, Y. (1999). Combustion characteristics and dioxin behavior of waste fired CFB. Chem. Eng. Sci. 54: 5599-5607.

Takaoka, M., Shiono, A., Nishimura, K., Yamamoto, T.,
Uruga, T., Takeda, N., Tanaka, T., Oshita, K., Matsumoto, T. and Harada, H. (2005). Dynamic change of copper in fly ash during de novo synthesis of dioxins. Environ. Sci. Technol. 39: 5878-5884.

Vermeulen, I., Van Caneghem, J. and Vandecasteele, C. (2014). Indication of PCDD/F formation through precursor condensation in a full-scale hazardous waste incinerator. J. Mater. Cycles Waste Manage. 16: 167171.

Vogg, H., Metzger, M. and Stieglitz, L. (1987). Recent findings on the formation and decomposition of PCDD/PCDF in municipal solid waste incineration. Waste Manage. Res. 5: 285-294.

Wang, L.C., Lee, W.J., Lee, W.S., Chang-Chien, G.P. and Tsai, P.J. (2003). Effect of chlorine content in feeding wastes of incineration on the emission of polychlorinated dibenzo-p-dioxins/dibenzofurans. Sci. Total Environ. 302: 185-198.

Wang, Y.H., Lin, C. and Chang-Chien, G.P. (2009). Characteristics of PCDD/Fs in a particles filtration device with activated carbon injection. Aerosol Air Qual. Res. 9: 317-322.

Wikström, E., Löfvenius, G., Rappe, C. and Marklund, S. (1996). Influence of level and form of chlorine on the formation of chlorinated dioxins, dibenzofurans, and benzenes during combustion of an artificial fuel in a laboratory reactor. Environ. Sci. Technol. 30: 16371644.

Xie, Y., Xie, W., Liu, K., Dicken, L., Pan, W.P. and Riley, J.T. (2000). The effect of sulfur dioxide on the formation of molecular chlorine during co-combustion of fuels. Energy Fuels 14: 597-602.

Yan, J., Chen, T., Li, X., Zhang, J., Lu, S., Ni, M. and Cen, K. (2006). Evaluation of PCDD/Fs emission from fluidized bed incinerators co-firing MSW with coal in China. J. Hazard. Mater. 135: 47-51.

Zhan, M., Wang, T., Yang, J., Ji, L., Zhou, G., Chen, T., Li, X. and Lin, X. (2018). The behaviors and relationships of PCDD/Fs and chlorobenzenes in the whole process of one municipal solid waste incinerator. Aerosol Air Qual. Res. 18: 3134-3146.

Received for review, March 27, 2019 Revised, April 21, 2019 Accepted, April 23, 2019 